\title{
Depression among Females in AL-Sader city, Baghdad, Iraq.
}

\author{
Hadeel M. Jasim * \\ Besma M. Ali* \\ Eman A. Al-Kaseer** \\ Jawad AL-Diwan**
}

\author{
FABHS \\ FICMS, \\ FIBMS, \\ DCN, FIBMS, FFPH
}

\section{Abstract:}

Background: Literature documented that depression is a sequlae of exposure to wars and widespread violence. In Iraq, high figures of depression were published.

Fac Med Baghdad Objectives: To report on prevalence of depression among women in high crowded area, Al-Sader city, 2017; Vol.59, No.3 Baghdad.

Method: A total of 440 females were included in this study. There were selected randomly from relatives of patients accompanied them in attending to primary health care centers. Beck -Depression Inventory (BDI)-II was used to assess depression. Demographic data were requested, too.

Result: The prevalence of depression was $68.4 \%$. Old age women, divorced and widows were determinants of depression. Education and crowding index (socioeconomic status) were not obvious determinants of depression.

Conclusion: High prevalence of depression was observed.

Keywords: depression, Al-Sader city, wars, violence, Iraq

\section{Introduction:}

In Iraq depression is a common disorder after wars an conflicts1, 2. Several articles documented this sequlae in Lebanon3and Syria4. Iraq was exposed to several wars in the last four decades5-7. Several reports documented the high prevalence of depression in Iraq1, 2, 8, 9. However, socioeconomic situation was neglected in studies on depression. Therefore, this study was carried out to demonstrate the effect of socioeconomic status on the rate of depression after wars.

\section{Materials and Methods:}

A total 440 females aged $31.2 \pm 8.5$ years were included in the study. They were recruited randomly from AL-Sader city for the period AugestDecember/2016. Al- Sader city is one of the most densely packed communities in the middle east 10 . They were apparently healthy attending Primary Health Care Center(PHCC), accompanied their children or relatives attending Antenatal Care (ANC) services in PHCC. Questionnaire lists including demographic data (age, education, marital status, occupation) and crowding index $(\leq 2$ not crowded, $>2$ crowded)11. Beck Depression Inventory (BDI)-II was used. It was invented in the last century. It has a known reliability and validity12. The result of BID is similar to that in DSM-IV-TR and DSM-513. A scale of $>10$ of BDI was considered depression. Variables were dichotomized e.g. age $\leq 20$ and $>20$. Chi-square was used to examine the association between dependent variable (depression) and independent variables (age, marital status, education, crowding index). $\mathrm{P}_{-}$ value $<0.05$ was considered significant.

*Ministry of Health, Primary Health Care Al-Sader city.E-mail: mhadeel12@yahoo.com

** Dept. of Community Medicine, College of Medicine.

\section{Result:}

Out of the total, $301(68.4 \%)$ were depressed. Of those depressed, $170(56.5 \%)$ had a mild depression and $131(43.5 \%)$ had a moderate or severe depression. Twenty one $(35.6 \%)$ females aged $\leq 20$ years were depressed, $280(73.5 \%)$ of those aged $>20$ years were depressed. Women aged >20years old had a significantly higher depression than those $\leq 20$ years $(\chi 2=34.49 \quad \mathrm{p}=0.00)$. Out of the single females, $20(45.4 \%)$ were depressed and 281 $(70.9 \%)$ of the married women were depressed. Marriage was a significant determinant of depression $(\chi 2=13.98 \quad \mathrm{p}=0.01)$. One hundred fourteen $(25.9 \%)$ were educated. Out of the illiterate females, $229(70.2 \%)$ were depressed and the 72 $(63.2 \%)$ of the educated females were depressed. The education was not significant determinant of depression $(\chi 2=2.089 \mathrm{p}=0.35)$. Depression among housewives was noticed in 278 (70.0\%) were depressed and $23(53.5 \%)$ of those working females were depressed. The working status was not significant determinant of depression $\left(\chi^{2}=4.909\right.$ $\mathrm{p}=0.086)$. Women lived in crowded houses $(>2$ crowding index) were $381(86.6 \%)$. The depression was noticed in $267(70.1 \%)$ and in 34 (57.65) among women in the non crowding houses. There was no significant difference in depression among women living in crowded and non-crowded houses $(\chi 2=4.23$ $\mathrm{p}=0.121$ ).

Table1. The sociodemograghic characteristics of the sample 440.

\begin{tabular}{llll}
\hline Variables & & $\mathrm{N}$ & $\%$ \\
\hline \multirow{2}{*}{ Age } & $\geq 20$ & 59 & 13.4 \\
\cline { 2 - 4 } & $<20$ & 381 & 86.6 \\
\hline \multirow{2}{*}{ Education } & uneducated & 326 & 74.1 \\
\cline { 2 - 4 } & educated & 114 & 25.9 \\
\hline \multirow{2}{*}{ Marital status } & Single & 44 & 10 \\
\cline { 2 - 4 } & married & 396 & 90 \\
\hline \multirow{2}{*}{ Occupation } & Housewife & 397 & 90.2 \\
\cline { 2 - 4 } & Working & 43 & 9.8 \\
\hline \multirow{2}{*}{ Crowding } & $\leq 2$ & 59 & 13.4 \\
\cline { 2 - 4 } & $>2$ & 381 & 86.6 \\
\hline
\end{tabular}


Table 2: The association between depression and variables.

\begin{tabular}{|c|c|c|c|c|c|}
\hline \multirow[b]{3}{*}{ Age (years) } & \multicolumn{5}{|c|}{ Depression } \\
\hline & \multicolumn{3}{|l|}{ Mild } & \multicolumn{2}{|c|}{$\begin{array}{l}\text { Moderate } \\
\text { \& severe }\end{array}$} \\
\hline & Total & $\mathrm{N}$ & $\%$ & $\mathrm{~N}$ & $\%$ \\
\hline$\leq 20$ & 59 & 14 & 23.7 & 7 & 11.9 \\
\hline \multirow[t]{2}{*}{$>20$} & 381 & 156 & 40.9 & 124 & 32.5 \\
\hline & 440 & \multicolumn{2}{|c|}{$\chi 2=34.49$} & \multicolumn{2}{|c|}{$\mathrm{p}=0.00$} \\
\hline Marital st. & Total & $\mathrm{N}$ & $\%$ & $\mathrm{~N}$ & $\%$ \\
\hline Single & 44 & 15 & 34.1 & 5 & 11.4 \\
\hline \multirow{2}{*}{ Married } & 396 & 155 & 39.1 & 126 & 31.8 \\
\hline & 440 & \multicolumn{2}{|c|}{$\chi 2=13.98 \quad \mathrm{df}=2$} & \multicolumn{2}{|c|}{$\mathrm{p}=0.01$} \\
\hline Education & Total & $\mathrm{N}$ & $\%$ & $\mathrm{~N}$ & $\%$ \\
\hline illiterate & 326 & 128 & 39.3 & 101 & 31 \\
\hline \multirow[t]{2}{*}{ Educated } & 114 & 42 & 36.8 & 30 & 26.3 \\
\hline & 440 & \multicolumn{2}{|c|}{$\chi 2=2.089$} & \multicolumn{2}{|c|}{$\mathrm{p}=0.35$} \\
\hline Working & Total & $\mathrm{N}$ & $\%$ & $\mathrm{~N}$ & $\%$ \\
\hline Housewife & 397 & 157 & 39.5 & 121 & 30.5 \\
\hline \multirow[t]{2}{*}{ Working } & 43 & 13 & 30.2 & 10 & 23.3 \\
\hline & 440 & \multicolumn{2}{|c|}{$\chi 2=4.909 \quad \mathrm{df}=2$} & \multicolumn{2}{|c|}{$\mathrm{p}=0.086$} \\
\hline Crowding & Total & $\mathrm{N}$ & $\%$ & $\mathrm{~N}$ & $\%$ \\
\hline$\leq 2$ & 59 & 17 & 28.8 & 1 & 28.8 \\
\hline \multirow[t]{2}{*}{$>2$} & 381 & 153 & 40.2 & & 29.9 \\
\hline & 440 & $\chi^{2}=4$ & $\mathrm{df}=2$ & \multicolumn{2}{|c|}{$\mathrm{p}=0.121$} \\
\hline
\end{tabular}

\section{Discussion:}

The rate of depression was $68.4 \%$. This high figure is in accordance with that reported by the IMHS2 and AL-Hamzawi et al1 in Iraq. High figure of depression was explained by exposure to wars and widespread violence. The exposure was the possible explanation in IMHS2. Economic hardship in Iraq was demonstrated in several reports13. This hardship was induced by wars and conflicts i.e. internally displaced people from other sites in Baghdad were migrated to this city10, 14. Economic hardship might be an added factor to explain depression. Literature documented the negative effect of economic hardship on the mood15. This study was carried out in highly crowded area ALSader city in Baghdad which is one of the most densely packed communities in the middle east 10 and exposed to violence and conflicts 8,16 . This crowded miserable situation might be an added reason for depression i.e there is no depression out of blue. Economic hardship is a detrimental of depression15. Age was significantly associated with depression $(p=0.00)$. Several articles documented the effect of age on the prevalence of depression 17,18 . An accumulation of exposure to events (wars \&violence) might be the possible explanation for this finding. Similar explanation was provided in Syria4. Different explanations were provided in western countries i.e loneliness, retirement due to age etc were reported17, 18. Highly significant prevalence rate of depression among divorced women and widows $(\mathrm{p}=0.01)$. Several studies showed that widows \& divorced women were deplored in society. In the 3rd world the solution is complex due to unique social, cultural, and economic milieu. It was referred for that as a silent epidemic of depression in the middle East and North Africa19,20. The study, revealed no significant association between education and depression $(\mathrm{p}=0.35)$. It is in contrast with other studies 21,22 .
The difference might be attributed to social, cultural and economic differences with increased level of education which in turn affect the coping were be improved. Depression was not significantly affected by occupation $(\mathrm{p}=0.08)$ and its inconsistent with other studies 23 . The difference might be explained by the fact that the majority of the women in the studied sample were house- wives10. Socioeconomic status was not a significant determinant of depression $(\mathrm{p}=0.12)$. Socioeconomic status was reflected by crowding index 24 . This finding is in contrast with that in literature 15,25. The difference might be explained by the fact that the exposure to wars and violence are determinate for depression which masked the effect of the socioeconomic status. It might be that the high rate $(86.6 \%)$ of high crowding index i.e. the low socioeconomic status, affect the reported effect of socioeconomic status on depression.

\section{Conclusion:}

High depression was noticed among women in ALSader city. Exposure to war and violence might be the determinant of the depression.

\section{Author's Contribution:}

Hadeel Mohamed: collecting of data through interview of the women in the sample. Providing copies of BDI, sharing with analysis of the results

Besma Ali: Sharing with collection of data and getting the ethical consents

Eman A. Al-Kaseer: suggesting the problem and sharing with interview and sharing with analysis Jawad Al-Diwan: discussing the results and writing the manuscript

\section{References:}

1. AL-Hamzawi AO, Bruffaerts R, Bromet ET, ALKhafagi AM, Kessler RC. The Epidemiology of Major Depression Episode in the Iraqi General Population. Journal Pone.2005:1-14.

2. AL-Hasnawi S, Sadic S, Rasheed M, Baban AL, AL-Malak MM, Othman AY,et al. The Prevalence \& Correlates of DSM-IV disorder in the Iraq Mental Health Survey. World Psychiatry 2009;8:97-109.

3. Karam EG, Mneimneh ZN, Dimassitt, Fayyad $J A$, Karam AN, Nasser SC, et al. Life time Prevalence of Mental Disorders in Lebanon First Onset, Treatment, and Exposure to war. PloS Med.2008;5(4):e61.

4. AFP. After four years of war, Syrians plagued by depression. Wires.2015.

5. Iraq Family Health Survey Group. ViolenceRelated Mortality in Iraq from2002 to 2006. N Engl J Med 2008,358:484-493.

6. Burnham $G$, Lafla $R$, Doocy $S$, Roberts $L$. Mortality after the 2003 invasion of Iraq: Acrosssectional cluster sample survey. http://www.Thelancet.com. published online Oct.11.2006.

7. Fearson JD. Iraqs Civil War. Foreign Affairs 2007; 86:2-16. 
8. AL-Shawi AF, AL-Hamairy NJ, AL-Diwan JK, Tabin DH. Post -trumatic Stress Disorder Among University in Baghadad: A preliminary Report. Iraqi J. Comm.Med. 2011;24(4):287-290.

9. AL-Shawi AF. Prevalence of Depression Symptoms among internal displaced people in Iraq: A pilot study. Internal displaced people in Iraq: A pilot study. J Community Med Health Care.2016;1(1):1002.

10. Carpenter AC. Community resilience to sectarian violence in Baghdad. Christie DJ(ed). Springer. New York 2014.

11. World Bank. Confronting Poverty in Iraq: main findings. Washington. DC: World Bank. http://documents.worldbank/curated/en/confrontingpoverty-in-iraq-main-findings

12. Kliem S, Moble T, Zenger M, Brahler $E$. Reliability \& Validity of The beck depression inventory-Fast screen for medical patients In the general German Population. J Affect Disord 2014;156: 236-9.

13. Williams DT, Cheadle JE. Economic Hardship, Parents Depression and Relationship Distress among couples with Young children. Soc Ment Health2016;6(2):73-89.

14. Iraq IDP Crisis. International Organization for Migration. Iraq. Mission 2016.

15. Wahlbeck K, A wolin M. The Impact of Economic Crisis on The Risk of Depression and Suicide: Aliterature Review. A Supporting Documents for the EU Thematic Conference on Preventing Depression and Suicide. Budapest. 2009. $P(1-10)$.

16. Canetti D, Gatea S, Hall BJ, Johnson RJ, Palmier PA, Hobfoll SE. Exposure to prolonged Socio-Poltical conflicts and the risk of PSTD and depression among
17. Mirowsky J, Ross C. Age and the Effect of Economic Hardship on Depression. J Health Social Behavior. 2001;42(2):132-150.

18. Gallo JJ, Anthony JC, Muthen BO. Age Differences in the Symptoms of Depression: A latent Trial Analysis. Journal of Gerontology: Psychological sciences. 1994;49(6):251-264.

19. Trivedi JK, Sareen H, Dhyani M. Psychological aspects of Widowhood and divorce. Mens Sana Monograghs 2009;7(1): 37-49.

20. Eloul L, Ambusaidi A, AL- Adwis. Silent epidemic of depression In women in the middle east and north Africa region. Sultan Qaboos Univ Med J.2009; (1):5-15.

21. Joury $A U, A L$ Atim $A A, A L$ Babtain $S A, A L$ sharif $M, A L$ Babtain NA, Mogbil AB, et al. Prevalence of depression and its Association with sociodemograghic characteristics among the general population. Int J Mod. Alt. Med. Res. 2014;(2):8-12.

22. Danish NA, Landeen J. Relation between depression and Socio- Demographic factors. International Journal of Mental Health Systems 2007;1(4):1-9.

23. Rodriguez, E, Frongillo, E. A \& Chandra. Do social programmes Contribute to mental well-being? The Long - Term impact of unemployment on depression in the United States. Int J. Epid. 2001;30(1):163-170.

24. Melkis S, Beydoum HA, Khogali M, Tamin H, Yunis KA. House hold Crowding index: a correlate of socioeconomic status and Interpregnancy spacing in un urban setting. J Epidemiol Community Health 2004;58:476-480.

25. Lorant V, Croux $C$, Weich S, Deliege D, Mackenbach J, Anasseau M. Depression and Socioeconomic risk factors: 7-year Longitudinal Population study. The British $J$ of Pych. 2007;190(4):293-298. 